\title{
Opinions of healthcare students on organ and tissue donation for transplantation
}

\author{
Opiniões de estudantes de saúde sobre a doação de órgãos e tecidos para transplante
}

Opiniones de estudiantes del área de la salud sobre la donación de órganos y tejidos para trasplante

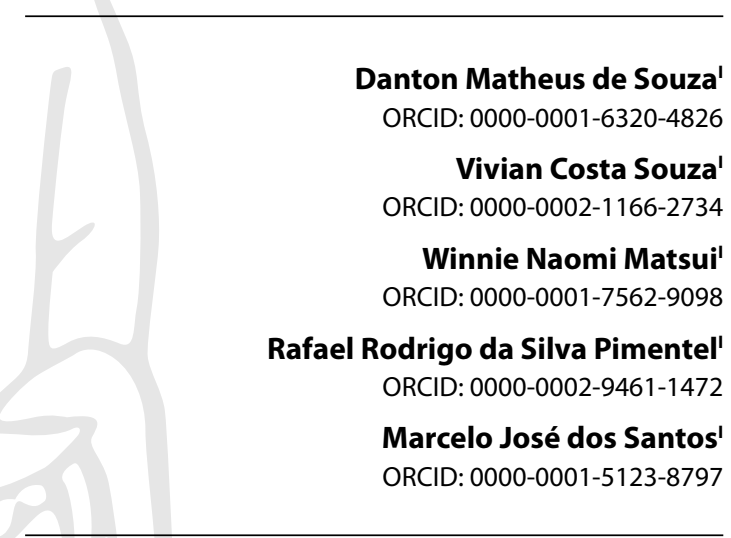

'Universidade de São Paulo. São Paulo, São Paulo, Brazil.

How to cite this article:

Souza DM, Souza VC, Matsui WN, Pimentel RRS, Santos MJ. Opinions of healthcare students on organ and tissue donation for transplantation. Rev Bras Enferm. 2022;75(3):e20210001. https://doi.org/10.1590/0034-7167-2021-0001

Corresponding author:

Danton Matheus de Souza

E-mail: Danton_souza@usp.br

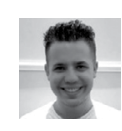

EDITOR IN CHIEF: Antonio José de Almeida Filho ASSOCIATE EDITOR: Priscilla Valladares Broca

Submission: 01-17-2021

Approval: 06-25-2021

\begin{abstract}
Objectives: to analyze the opinions of healthcare students on organ and tissue donation for transplantation. Methods: qualitative document analysis study, using the records of a database and analyzing data from two perspectives: 1) Lexical analysis, with the IRAMUTEQ software, and 2) Thematic content analysis. Results: from the analysis, 3 main categories were generated: 1) Organ and tissue donation as an act of love for others and an opportunity of a new beginning; 2 ) Clarification and awareness on organ and tissue donation; and 3) Importance of communicating the family and promoting organ and tissue donation. Final Considerations: despite being in favor of donation, students also recognize the presence of social taboos; the discussion in the family nucleus, promoting the theme and raising awareness in society are considered important. Additionally, the education of students is one of the possibilities of intervention for the issue.

Descriptors: Public Opinion; Students, Health Occupations; Tissue and Organ Procurement; Health Education; Qualitative Research.
\end{abstract}

\section{RESUMO}

Objetivos: analisar as opiniões de estudantes de cursos da saúde sobre a doação de órgãos e tecidos para transplante. Métodos: estudo qualitativo, com desenho de análise documental, a partir de registro de um banco de dados, analisados sob duas óticas: 1) Análise lexical, com o software IRAMUREQ, e 2) Análise temática de conteúdo. Resultados: da análise, geraramse 3 categorias principais: 1) Doação de órgãos e tecidos como ato de amor ao próximo e oportunidade de recomeço; 2) Desmistificação e conscientização sobre doação de órgãos e tecidos; e 3) Importância de comunicar a família e divulgar a doação de órgãos e tecidos. Considerações Finais: apesar dos estudantes demonstrarem opiniões favoráveis à doação, também reconhecem a presença de tabus sociais, sendo importante a discussão em núcleo familiar, a divulgação da temática e a conscientização da sociedade. Além disso, a educação dos discentes torna-se uma das possibilidades de intervenção na problemática.

Descritores: Opinião Pública; Estudantes de Ciências da Saúde; Obtenção de Tecidos e Órgãos; Educação em Saúde; Pesquisa Qualitativa.

\section{RESUMEN}

Objetivos: analizar las opiniones de estudiantes de cursos de la salud sobre la donación de órganos y tejidos para trasplante. Métodos: se trata de un estudio cualitativo, con diseño de análisis documental, a partir del registro de un banco de datos, considerado bajo dos ópticas: 1) Análisis lexical, con el software IRAMUREQ, y 2) Análisis temático de contenido. Resultados: del análisis se generaron 3 categorías principales: 1) Donación de órganos y tejidos como acto de amor al prójimo y oportunidad de recomenzar; 2) Desmitificación y concienciación sobre la donación de órganos y tejidos; e 3) Importancia de comunicar a la familia y divulgar la donación de órganos y tejidos. Consideraciones Finales: a pesar de que los estudiantes hayan mostrado opiniones favorables hacia la donación, reconocen, también, la existencia de tabúes sociales, haciéndose necesaria la discusión en el núcleo familiar, la divulgación de la temática y la concienciación de la sociedad. Una de las posibilidades de intervención en la problemática es la educación de los alumnos.

Descriptores: Opinión Pública; Estudiantes del Área de la Salud; Obtención de Tejidos y Órganos; Educación en Salud; Investigación Cualitativa. 


\section{INTRODUCTION}

Worldwide, the number of patients on the transplant waiting list has increased over the years, mainly due to non-communicable chronic diseases and the population's lifestyle. Consequently, the number of donations has become insufficient to cover the demand $^{(1-2)}$. This reality is also seen in Brazil, where in 2020, 10.618 potential donors were identified, but only 3.323 (31.29\%) came through ${ }^{(3)}$.

The insufficient number of donations may be related to lack of knowledge about the protocol and difficulty in diagnosing brain death; underreporting; maintenance of potential donors; medical contraindications, such as infections ${ }^{(4)}$; lack of professional skill in family interviews; professionals who are against organ donation, who work with unreasonable obstinacy and/ or provide inconsistent information to relatives; circumstances of the interview, such as location, healthcare team, verbal and non-verbal communication ${ }^{(4-5)}$; and the refusal of families ${ }^{(6-7)}$.

Although part of society views organ donation as an act of solidarity and love ${ }^{(8)}$, there are negative beliefs around the subject, related to lack of knowledge about the process, which influence individuals in the decision to donate or not their and/or their relatives' organs and tissues ${ }^{(1,9-10)}$. In Brazil, Law No. 10.211/2001 ${ }^{(11)}$ determines that, for organ donation, there must be a diagnosis of brain death and the informed consent of relatives up to the second degree. These family members often decline to donate due to many reasons, such as: not understanding the situation; religious beliefs; fear of mutilation and threat to the entirety of the body; organ trade; professional negligence; impossibility of knowing the recipient; fear of the reaction of other family members; or inappropriate interview ${ }^{(5,7,10,12-13)}$.

The performance of health professionals, especially during the family interview, can reinforce or debunk negative beliefs about organ donation, as these professionals are the link between the population and the health system and have credibility in society ${ }^{(2,5,14)}$. However, the literature demonstrates the unpreparedness of professionals in the entire donation process; this may be associated with their training ${ }^{(15)}$, as there is a gap in the curricula, especially in nursing courses ${ }^{(1,15-18)}$.

The insufficient incorporation of the theme in undergraduate curricula was demonstrated in a Mexican study with 331 students of health courses, which found that among the 143 (43.2\%) nursing students, only $13(9 \%)$ had some training on organ and tissue donation. Among the 188 (56.8\%) medical students, only 75 (39.8\%) had contact with the subject, which demonstrates that this challenge is present in both trainings ${ }^{(1)}$.

Students in the health area will be health professionals and have a relevant role in the process of organ and tissue donation for transplantation. Thus, the following question is presented: what is the opinion of students in the health area on the subject? It is important to know and analyze the opinions of these students on the theme of organ and tissue donation for transplantation in order to identify gaps in their training process and their concerns, attitudes, beliefs and prior knowledge, which may be reinforced, corrected or resignified still at university, so that, in professional life, they can contribute to the reduction of the transplant waiting list through teaching and care.

\section{OBJECTIVES}

To analyze the opinions of healthcare students on organ and tissue donation for transplantation.

\section{METHODS}

\section{Ethical Aspects}

The study was submitted to the Research Ethics Committee for Human Beings and approved, as determined by Resolution No. 466 of 2012, of the National Health Council.

\section{Type of Study}

A qualitative document analysis study using the Consolidated Criteria for Reporting Qualitative Research - COREQ ${ }^{(19)}$ to guide its development.

\section{Study Setting}

The study was carried out in a public higher education institution in the Southeast Region of Brazil.

\section{Data Source}

The data came from an extension project's database. The archived documents had been collected before an educational action carried out in the National Organ Donation Campaign, in 2019, with the university community of a public higher education institution. The population included, among others, students of health courses - speech therapy, physical therapy, nutrition, medicine and nursing - who were invited, voluntarily and anonymously, to answer the following question on a piece of paper: "What is your opinion about the donation of organs and tissues for transplantation?". At the time, the only objective of the action was collecting the opinions of students, and with their approval, projecting them to the public during the final event of the campaign; for this reason, the Informed Consent Form was not applied.

\section{Data Collection and Organization}

After obtaining the agreement of the extension project coordinator, the records were transcribed in full and organized in Microsoft Word 2013. All records available in the file were included and those that were illegible or compromised by damage suffered during storage were excluded. Subsequently, the records were read, language vices were removed, and files were organized for analysis. Opinions are identified in the text as $\mathrm{O}$ (opinion) and arabic numerals to identify the respondents.

\section{Data Analysis}

The transcribed opinions were analyzed with two approaches. The first was lexical analysis, using the software: Interface de $R$ pour les Analyse Multidimensionnelles de Textes et de Questionnaires (IRAMUTEQ) version 0.7 Alpha 2 and RVersion 3.2.3. This program allows a quantitative analysis of qualitative data and is relevant to the study of thoughts, beliefs, experiences, perceptions and opinions ${ }^{(20)}$. In this 
analysis, the transcribed reports formed the textual corpus and the Text Segments (TS) and groups of statistically significant words were identified $^{(21)}$. The results identified with the tool can be organized in different ways; in this case, the authors chose the two ways most suitable to the objective of the study: 1) Descending Hierarchical Analysis (DHA), in which the words with statistical significance, identified by the chi-square test $\left(\mathrm{X}^{2}\right)$, with a value greater than 3.84 , are organized into classes ${ }^{(20)}$; and 2) Similarity analysis, based on the graph theory and carried out according to the occurrences of words in the text segments ${ }^{(21)}$, illustrating the origin and connection of words.

After the organization of the analysis, the names of the classes were defined through exhaustive reading of the text segments in correlation with the frequency of the terms in the vocabulary, to unveil, with rigor and depth, the real meaning of the opinions. Then, in thematic content analysis, the opinions were read countless times, in a stage known as thorough reading. After mastering the data, the stages of extraction of meanings, coding, categorization, and correlation of the information collected with the objective of the research were performed ${ }^{(22)}$. Thus, the following main categories and subcategories were generated: 1) Organ and tissue donation as an act of love for others and an opportunity for a new beginning, 1.1) An act of love for others, and 1.2) An opportunity for a new beginning; 2 ) Clarification and awareness on organ and tissue donation; 2.1) The social taboo of organ and tissue donation for transplantation, and 2.2) Inefficient communication of organ and tissue donation in the social environment; 3) Importance of communicating the family and promoting organ and tissue donation, 3.1) Importance of communicating the family about organ and tissue donation; and 3.2) Importance of promoting the theme. The lexical analysis and thematic content analysis were organized in order to complement each other for a better understanding of the data. Thus, the classes and categories were named in similar ways.

\section{RESULTS}

In the file, 100 records with the opinions of students were identified; however, 1 was excluded because it was illegible. Thus, 99 written opinions composed the database and were included in this study, constituting the general corpus. These opinions were separated into 103 text segments (TS), of which 81 (78.64\%) were used. A total of 2017 occurrences were generated (words, forms or vocabularies), of which 625 were distinct words and 398 had a single occurrence. The content analyzed was categorized into 3 classes, namely, class 1, with 33 TS (40.74\%); class 2, with 17 TS (20.99\%) and class 3, with 31 TS (38.27\%).

The three classes of the Descending Hierarchical Classification (DHC) have two branches: the subcorpus $A$ and $B$ of the total corpus. Subcorpus A is part of Class 3 ("Organ and tissue donation as an act of love for others and an opportunity for a new beginning"), which refers to the students' opinion on organ donation as an act of solidarity that provides a new opportunity. Subcorpus B is composed of Class 1 ("Importance of communicating the family and promoting organ and tissue donation"), which highlights the importance of expressing the desire to be a donor to the family and the dissemination of the subject; and Class 2 ("Clarification and awareness on organ and tissue donation"), which expresses the taboos and the need for knowledge regarding organ and tissue donation (Figure 1).

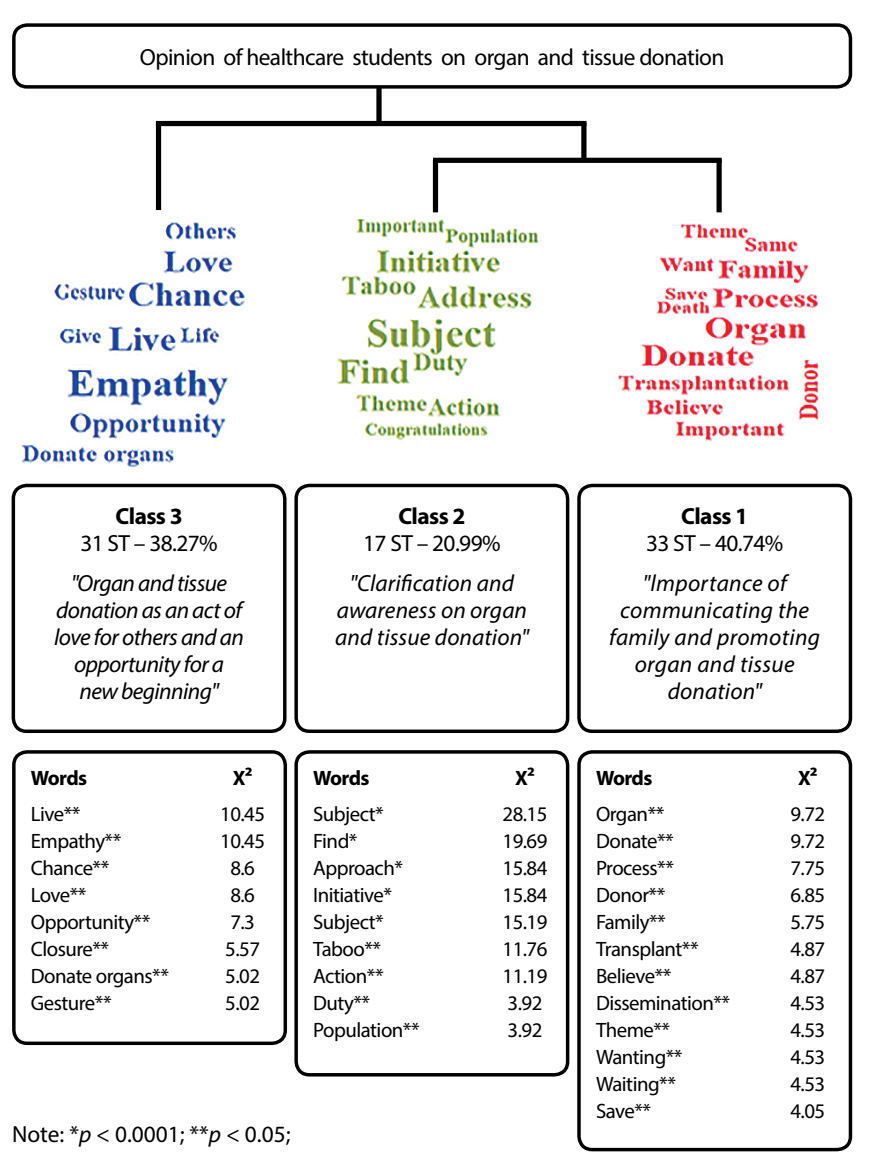

Figure 1 - Dendrogram of the descending hierarchical classification of the corpus of healthcare students' opinions about organ and tissue donation, São Paulo, São Paulo, Brazil, 2021

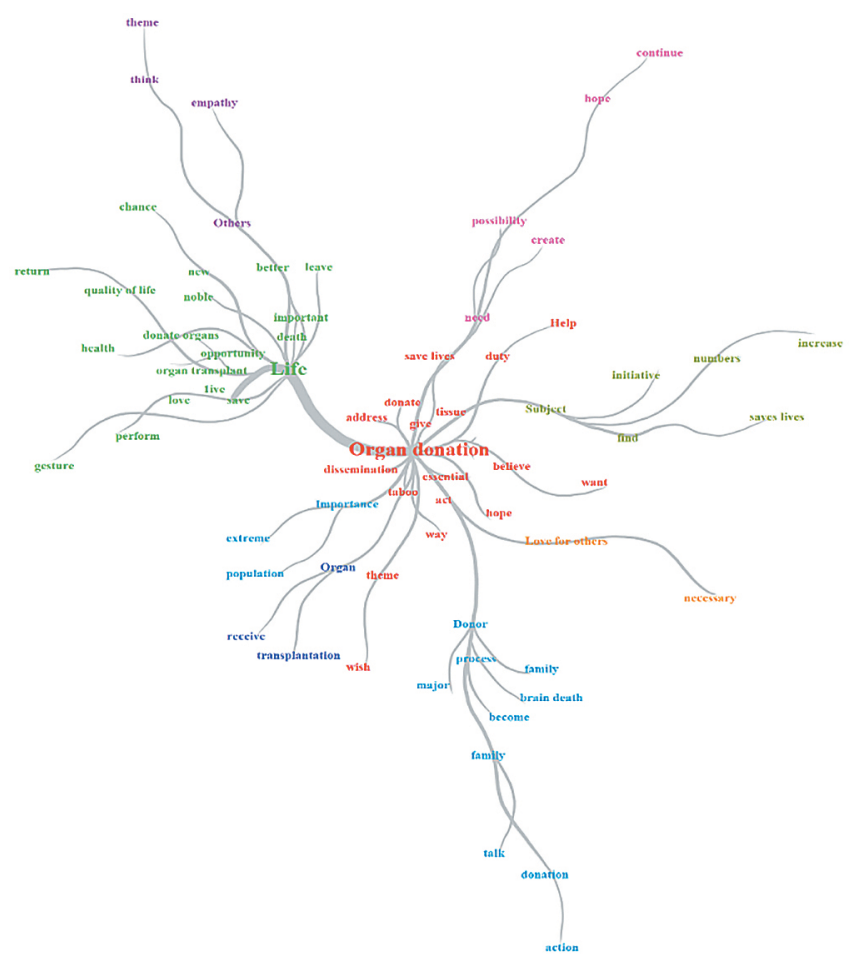

Figure 2 - Similarity analysis, São Paulo, São Paulo, Brazil, 2021 
Figure 2 shows the similarity analysis, which portrays the relationship between the segment "organ donation" (doação de órgãos) and words related to the opinion of students: organ donation as an act that saves the "life" (vida) of those who"need" (precisar) and the "importance" (importância) of disseminating the "subject" (assunto), of being a "donor" (doador) and of talking to the "family" (família), in addition to the "taboo" (tabu) regarding the theme.

\section{Organ and tissue donation as an act of love for others and an opportunity for a new beginning}

The subcategory "An act of love for others" shows that students see the donation of organs and tissues for transplantation as a possibility to show solidarity, empathy, love and transform a difficult moment into a moment of hope that can be gratifying. Donation is also seen as a chance for the other to recover from the impact of illnesses, improving their quality of life and giving them the chance to continue their history, which can be observed in the subcategory "An opportunity for a new beginning".

\section{Clarification and awareness on organ and tissue donation}

The subcategory"The social taboo of organ and tissue donation for transplantation" shows that students recognize the myths regarding the donation process that are present in the social environment, which may be a consequence of the population's ignorance, and their relationship with death and the process of dying, which demonstrates that education is a way to debunk previous beliefs. Lack of knowledge is also mentioned in the subcategory "Inefficient communication of organ and tissue donation in the social environment", which refers to the low awareness and dissemination of the subject, which affect the population's beliefs.

\section{Importance of communicating the family and promoting organ and tissue donation}

The subcategory "Importance of communicating the family about organ and tissue donation" shows that students feel the need to have an open space within the family to express their wish to be donors and talk about the subject. However, some reported not having this space, due to fear of dialogue, factors related to religion, negative reactions, and stigma of brain death. Nevertheless, they recognize the importance of having this conversation with relatives, so they can be aware of the donation. In this regard, they report that health professionals and population must join efforts to achieve this goal (subcategory: importance of promoting the theme).

Chart 1 presents the opinions of students in relation to the aforementioned subcategories.

Chart 1 - Opinions of health students on organ and tissue donation for transplantation: categories and subcategories. São Paulo, São Paulo, Brazil, 2021.

\begin{tabular}{|c|c|c|}
\hline MAIN CATEGORY & SUBCATEGORIES & OPINIONS \\
\hline \multirow{2}{*}{$\begin{array}{l}\text { Organ and tissue donation } \\
\text { as an act of love for others } \\
\text { and an opportunity for a } \\
\text { new beginning }\end{array}$} & An act of love for others & $\begin{array}{l}\text { The importance of organ donation goes beyond detachment from the flesh, body, or } \\
\text { figure of our loved ones. It's about love for others, it's about doing good deeds without } \\
\text { knowing to whom, it's about giving life to those who have reasons to live [...]. (O16) } \\
\text { I think it's a gesture of love, because, in addition to saving a life, you can give someone } \\
\text { their quality of life back, give them the opportunity to live life to the fullest. (O49) }\end{array}$ \\
\hline & $\begin{array}{l}\text { An opportunity for a new } \\
\text { beginning }\end{array}$ & $\begin{array}{l}\text { Organ donation for me, in addition to representing a very altruistic gesture, also creates } \\
\text { possibilities and life opportunities for those who need them. Donations in life and after } \\
\text { death are equally noble and effective. (O44) }\end{array}$ \\
\hline \multirow{2}{*}{$\begin{array}{l}\text { Clarification and awareness } \\
\text { on organ and tissue } \\
\text { donation }\end{array}$} & $\begin{array}{l}\text { The social taboo of organ } \\
\text { and tissue donation and } \\
\text { transplantation }\end{array}$ & $\begin{array}{l}\text { Organ donation is an extremely important issue for public health. Unfortunately, the } \\
\text { population is not aware about this fact, and there are still several taboos about the } \\
\text { subject. (O20) } \\
\text { I realize that this theme is still taboo because it is closely linked to the process of death } \\
\text { and dying. I think the more we promote the theme and make our will clear, we can } \\
\text { contribute to the lives of others. (O63) }\end{array}$ \\
\hline & $\begin{array}{l}\text { Inefficient communication of } \\
\text { organ and tissue donation in } \\
\text { the social environment; }\end{array}$ & $\begin{array}{l}\text { I believe that the theme of organ donation and transplantation, as well as in the health } \\
\text { area in general, is not sufficiently disseminated to the Brazilian population when it } \\
\text { comes to its importance and contribution to health maintenance [...]. (041) } \\
\text { My perception about organ donation is that there is still little publicity about its } \\
\text { importance [...]. (O60) }\end{array}$ \\
\hline \multirow{2}{*}{$\begin{array}{l}\text { Importance of } \\
\text { communicating the family } \\
\text { and promoting organ and } \\
\text { tissue donation }\end{array}$} & $\begin{array}{l}\text { Importance of communicating } \\
\text { the family about organ and } \\
\text { tissue donation }\end{array}$ & $\begin{array}{l}\text { I think it's very important, I always tell my family about the importance and about my } \\
\text { desire to be a donor. Unfortunately, people talk very little about organ donation and } \\
\text { death, which are very important issues. (O47) } \\
\text { [...] I don't know if my family would be okay with this, because it is something that is not } \\
\text { well known, they might be afraid. (O74) } \\
\text { I would really like to propose this to my family, but I'm not sure how to talk about it as } \\
\text { they are very religious. (O62) }\end{array}$ \\
\hline & $\begin{array}{l}\text { Importance of promoting the } \\
\text { theme }\end{array}$ & $\begin{array}{l}\text { Organ donation is essential, and the idea should be more widespread and people } \\
\text { should be more educated on the subject, so that the number of donors can increase. } \\
\text { (O94) } \\
\text { The promotion of organ donation needs to be given greater emphasis. Many people are } \\
\text { unaware of the process [....]. (O46) }\end{array}$ \\
\hline
\end{tabular}




\section{DISCUSSION}

In this study, organ and tissue donation for transplantation was seen by the students as an act of love for others that can provide a new life for the recipient. These results are corroborated by a Spanish study ${ }^{(17)}$ with 9.275 medical students, of which 7.420 $(80 \%)$ were in favor of organ donation and viewed the act as a way of demonstrating solidarity and love for others.

In Brazil, an investigation carried out with 57 nursing students found that 17 (30\%) had favorable opinions, expressing their interest in being a donor and citing the opportunity to help others as justification for this choice ${ }^{(23)}$.

Students in this study also believe that donation saves lives. This perception was also identified in studies carried out with the general population in Malaysia and Turkey ${ }^{(2,9)}$. This idea seems to be widespread and common in the representation of organ and tissue donation in society, which includes health care students.

It is worth noting that the fact of perceiving donation as an act of love for others, of solidarity or as an act that saves lives contributes to a favorable decision, but it is not the determining factor in the choice to be a donor or consent to harvesting a relative's organs. The individual may have positive perceptions, but this does not mean that there is a real desire to be a donor ${ }^{(9-10,24)}$. In this direction, a Spanish study identified that 1.855 (20\%) medical students interviewed were undecided or would deny the donation, a high number considering the area of training ${ }^{(17)}$. A similar percentage was found in a Brazilian study with nursing students, in which $17.5 \%$ were not donors, due to their negative beliefs about the subject ${ }^{(23)}$.

Among health professionals, studies conducted in Ethiopia ${ }^{(14)}$, Nigeria ${ }^{(25)}$, and Malaysia ${ }^{(26)}$ found rates of refusal to donate organs and tissues similar and even higher than those identified in research with students of the area. These data are intriguing and demonstrate that even more educated individuals have doubts about whether or not to donate organs. However, it must be noted that these positions can be influenced by social, cultural, religious, economic, and political aspects. These findings lead us to think that "if students and/or health professionals have insecurity and doubt regarding the donation, let alone lay people and family members recently impacted by the loss of a relative".

A study carried out in Malaysia with 383 individuals showed that 189 (49\%) were against or were undecided about organ donation. In Turkey, a survey with 4.000 people showed that 988 (24.7\%) had negative attitudes towards organ donation due to beliefs marked by the taboo of the subject in society ${ }^{(9)}$.

In this study, students recognize the presence of social taboos that hinder the donation process. A literature review with 21 studies found that the factors influencing the opinions of health care students about donation included the opinion of relatives, religion, perception of how the body looks after donation, and previous discussions about the subject with friends and/or family ${ }^{(27)}$.

Taboos are present in different countries and different populations. In general, these taboos are related to beliefs such as the existence of an organ trade market, the practice of euthanasia by health professionals, and the disfigurement of the body after donation. These perceptions are very common and contribute to attitudes against organ donation ${ }^{(7,10,18,24)}$. This is corroborated by a Mexican study carried out with 331 medical and nursing students, in which it was possible to identify these beliefs, along with fear of pain during the surgical procedure or negligence of professionals ${ }^{(1)}$. These data are similar to those found in a survey with health professionals ${ }^{(14)}$.

It should be noted that the perceptions about the organ and tissue donation process are influenced by knowledge on the subject. Therefore, in the case of healthcare students, undergraduate teaching has a fundamental role in this aspect and in the formation of future professionals. However, a survey carried out with nursing students in Spain found that the time dedicated to this topic is limited ${ }^{(15)}$. Similarly, a German study showed that $47.1 \%$ of the healthcare students interviewed believed that the information received during their training were insufficient ${ }^{(18)}$.

Deficits in training will appear and can be observed in professional practice. This fact was demonstrated in an investigation with 264 professionals of the nursing team in Serbia, of whom 4 (1.5\%) believed that the family does not need support after the death of a loved one and in the beginning of the organ donation process $^{(28)}$. Although the number is small, it is important to point out that individuals with higher education and/or technical training that should include the topic of organ donation also have beliefs that negatively impact the process. With this, we ask: how is the decision-making process of families affected when they are approached by a professional who is not trained to deal with the issue of organ and tissue donation for transplantation?

There is no doubt that professionals trained to deal with the subject can facilitate the decision-making by those responsible and increase the number of donations by welcoming them, providing explanations about the process, and clearing any doubts they have. This fact was demonstrated in a study carried out in the Netherlands, which found that family consent rate for donation was greater when guidance was provided by trained professionals ${ }^{(6)}$. On the other hand, there are professionals who still act inappropriately and may lead relatives to refuse the donation ${ }^{(4-5)}$.

Regarding the importance of communicating the family and promoting organ donation, the students in this study recognize the importance of including family members in conversations in life about donation, but some prefer not to address the issue in order to avoid conflict. In this sense, the literature shows reports of the difficulty of discussing the subject with relatives due to lack of time, knowledge, experience or the prior expression of opinions against organ donation ${ }^{(1)}$.

A survey conducted in Turkey with 240 students from different healthcare courses showed that $170(70.9 \%)$ had not talked about the subject with their family. Similarly, a study carried out with Asian Americans found that, among the 64 respondents, many had not addressed the subject with their relatives, even though half of them showed favorable attitudes about donation ${ }^{(24)}$. Thus, it is important to have public policies that inform the population and encourage dialogue on the subject, especially in the family nucleus.

It is important to highlight that, although academic training in the health area presupposes that individuals have greater knowledge on the subject, there is still the need for approaches that, in addition to scientific knowledge, also seek to understand the values and agents involved in the process. It is also worth noting 
that addressing the matter by itself may not be effective, as it is necessary to recognize the context in which the students are inserted and provide them with a reflection on their social role, increasing their interest and engagement in the topic, in conjunction with promotion and awareness-raising actions by the government.

The students in this study pointed out the importance of promoting the theme, considering this as a unique opportunity to raise awareness and prompt change in attitudes towards donation. This promotion must be clear and try to reach the greatest number of people through various strategies, such as social media, news, printed material, lectures and educational actions ${ }^{(9)}$.

Finally, we highlight that the findings in the literature demonstrate that healthcare students who study the topic during their education often have favorable attitudes towards donation and develop a theoretical framework with valid arguments for the dialogue with the public ${ }^{(15-16,27)}$.

\section{Study limitations}

A limitation of the study is the fact that the records of archived opinions did not present information on variables that could contribute to the discussion of the study.

\section{Contributions to the health area}

This study helps understanding the opinions of students regarding organ and tissue donation for transplantation, demonstrating the presence of social taboos, and the importance of discussing the topic with the family nucleus and society, which can be carried out through public policies and educational actions. Additionally, it can guide discussions on the matter in academic training spaces, aiming to elucidate and resignify possible beliefs.

\section{FINAL CONSIDERATIONS}

Healthcare students have a favorable view of organ and tissue donation for transplantation but recognize that the process is marked by social taboos that influence society. In addition, they mention the importance of educational and awareness-raising actions on the subject to create a space for discussion, especially in the family context. Thus, it is worth noting that the education of healthcare students on the subject is one of the possibilities of intervention for the problem, as they are the link between the lay public and the scientific community, and can promote discussions, debunk myths and provide qualified assistance.

\section{REFERENCES}

1. Marvan ML, Cortés FO, Río AA. General knowledge and attitudes toward organ donation in a sample of Mexican Medical and Nursing Students. Rev Cienc Salud. 2020;18(2):1-19. https://doi.org/10.12804/revistas.urosario.edu.co/revsalud/a.9240

2. Lim KJ, Cheng TTJ, Jeffree MS, Hayati F, Cheah PK, Nee KO, et al. Factors influencing attitude toward organ and tissue donation among patients in primary clinic, Sabah, Malaysia. Transplant Proc. 2020;52(3):680-6. https://doi.org/10.1016/j.transproceed.2020.01.007

3. Associação Brasileira de Transplante de Órgãos. Dados Numéricos da doação de órgãos e transplantes realizados por estado e instituição no período: Janeiro / Dezembro - 2020. Registro Brasileiro de Transplantes [Internet]. 2020 [cited 2020 Mar 14];1-32. Available from: https://site. abto.org.br/publicacao/xxvi-no-4-anual/

4. Magalhães JB, Schulz RS, Borges TP, Barata RS, Sampaio KCP, Lima RR, et. al. Nursing challenges in the soft organ transplant donation: integrative review. Rev Eletron Acervo Saúde. 2020;12(10:1-10. https://doi.org/10.25248/reas.e4195.2020

5. Moraes EL, Silva LBB, Santos MJ, Lima EAA, Massarollo MCKB. Obstáculos no processo de doação de órgãos e estratégias para otimizar as taxas de consentimento familiar [Internet]. RBM: Rev Bras Med [Internet]. 2015 [cited 2020 Mar 26];72(1):5-11. Available from: http://www. moreirajr.com.br/revistas.asp?fase=r003\&id_materia=6115

6. Witjes M, Jansen NE, van Dongen J, Herold IHF, Otterspoor L, Haase-Kromwijk BJJM, et al. Appointing nurses trained in organ donation to improve family consent rates. Nurs Crit Care. 2020;25(5):299-304. https://doi.org/10.1111/nicc.12462

7. Knihs NS, Leitzke T, Roza BA, Schirmer J, Domingues TAM. Understanding the experience of families facing hospitalization, brain death, and interview for organ donation. Cienc Cuid Saude. 2015;14(4):1520-7. https://doi.org/10.4025/cienccuidsaude.v14i4.26060

8. Akbulut S, Ozer A, Gokce A, Demyati K, Saritas H, Yilmaz S. Attitudes, awareness, and knowledge levels of the Turkish adult population toward organ donation: study of a nationwide survey. World J Clin Cases. 2020;8(11):2235-45. https://doi.org/10.12998/wjcc.v8.i11.2235

9. Tontus HO. Educate, Re-educate, Then Re-educate: Organ Donation-centered Attitudes Should Be Established in Society. Transplant Proc. 2020;52(1):3-11. https://doi.org/10.1016/j.transproceed.2019.10.028

10. Abbasi P, Lebni JY, Nouri P, Ziapour A, Jalali A. The obstacles to organ donation following brain death in Iran: a qualitative study. BMC Med Ethics. 2020;21(1):83. https://doi.org/10.1186/s12910-020-00529-8

11. Presidência da República (BR). Lei n. 10.211 de março de 2001 [Internet]. 2001 [cited 2020 Mar 28]. Available from: http://www.planalto.gov. br/ccivil_03/leis/leis_2001/l10211.htm

12. Morais TR, Morais MR. Organ donation: you need to educate to advance. Saúde Debate. 2012;36(95):633-9. https://doi.org/10.1590/ S0103-11042012000400015

13. Pessoa JLE, Schirmer J, Roza BA. Evaluation of the causes for family refusal to donate organs and tissue. Acta Paul Enferm. 2013;26(4):323330. https://doi.org/10.1590/S0103-21002013000400005 
14. Girma A, Malu A, Shimeka A, Oumer M. Attitude, willingness, and associated factors in organ donation among health professionals in Gordan, Northwest Ethiopia. Transplant Proc. 2020;53(2):539-47. https://doi.org/10.1016/j.transproceed.2020.08.022

15. Alarcón LM, Rios A, Borredá ES, Suarez MC, Fuente GAC, Pardos BH, et al. Nursing students' knowledge about organ donation and transplantation: a Spanish Multicenter Study. Transplant Proc. 2019;51(9):3008-11. https://doi.org/10.1016/j.transproceed.2019.08.019

16. Skalli GD, Dag GS. Organ transplantation and donation from the point of view of college students. Transplant Proc. 2020;52(1):26-31. https:// doi.org/10.1016/j.transproceed.2019.11.008

17. Ríos A, Navas AL, Lopez AL, Iriarte GJ, Blanco HG, Llorca FJ, et al. A Multicentre and stratified study of the attitude of medical students towards organ donation in Spain. Ethn Health. 2019;24(4):443-61. https://doi.org/10.1080/13557858.2017.1346183

18. Tackmann E, Kurz P, Dettmer S. Attitudes and knowledge about post-mortem organ donation among medical students, trainee nurses and students of health sciences in Germany: a cross-sectional study. Anaesthesist. 2020;69(11):810-20. https://doi.org/10.1007/s00101-020-00812-8

19. Tong A, Sainsbury P, Craig J. Consolidated criteria for reporting qualitative research (COREQ): a 32-item checklist for interviews and focus groups. Int J Qual Health Care. 2007;19(6):349 -57. https://doi.org/10.1093/intqhc/mzm042

20. Souza MAR, Wall ML, Thuler ACMC, Lowen IMV, Peres AM. The use of IRAMUTEQ software for data analysis in qualitative research. Rev EsC Enferm USP. 2018;52:e03353. https://doi.org/10.1590/s1980-220x2017015003353

21. Camargo BV, Justo AM. IRAMUTEQ: a free software for analysis of textual data. Temas psicol 2013;21(2):513-8. https://doi.org/10.9788/ TP2013.2-16

22. Minayo MCS. O desafio do conhecimento: pesquisa qualitativa em saúde. 13 ed. São Paulo: Hucitec; 2013.

23. Bispo CR, Lima JC, Oliveira MLC. Organ donation: nursing undergraduate student's perspective. Rev Bioét. 2016;24(2):386-94. https://doi. org/10.1590/1983-80422016242139

24. Siminoff LA, Bolt S, Gardiner HM, Alolod GP. Family first: Asian Americans' attitudes and behaviors toward deceased organ donation. J Racial Ethn Health Disparities. 2020;7(1):72-83. https://doi.org/10.1007/s40615-019-00635-3

25. Esezobor Cl, Disu E, Oseni SBA. Attitude to organ donation among healthcare workers in Nigeria. Clin Transplant. 2012;26(6):612-6. https:// doi.org/10.1111/ctr.12032

26. Abidin ZLZ, Ming WT, Loch A, Hilmi I, Hautmann O. Are health professionals responsible for the shortage of organs from deceased donors in Malaysia? Transplant Int. 2013;26(2):187-94. https://doi.org/10.1111/tri.12019

27. Tsubaki M, Tougo S, Kobayashi M, Arakawa S, Yoshida K. Narrative review on attitudes toward organ donation of undergraduate nurse students. Jpn J Nurs Sci. 2020;17(1):e12291. https://doi.org/10.1111/jjns.12291

28. Vlaisavljevica Z, Jankovic S, Maksimovic N, Culafic M, Stulic M, Milovanovic T, et al. Attitudes of nurses toward organ donation in Serbia. Transplant Proc. 2020;52(3):673-9. https://doi.org/10.1016/j.transproceed.2020.01.031 